\title{
SSU rRNA Reveals a Sequential Increase in Shell Complexity Among the Euglyphid Testate Amoebae (Rhizaria: Euglyphida)
}

\author{
Enrique Lara $^{a, d}$, Thierry J. Heger ${ }^{a, b}$, Edward A.D. Mitchell ${ }^{a, b, 1}$, Ralf Meisterfeld ${ }^{c}$, and \\ Flemming Ekelund ${ }^{\mathrm{d}}$
}

\begin{abstract}
aWSL, Swiss Federal Research Institute, Ecosystem Boundaries Research Unit, Wetlands Research Group, Station 2, CH-1015 Lausanne, Switzerland

bécole Polytechnique Fédérale de Lausanne (EPFL), Laboratory of Ecological Systems (ECOS), Station 2, $\mathrm{CH}-1015$ Lausanne, Switzerland

${ }^{\mathrm{C} R W T H}$ Aachen, Institute for Biology II, Kopernikusstrasse 16, D 52056 Aachen, Germany

${ }^{\mathrm{d} T}$ Terrestrial Ecology, Biological Institute, University of Copenhagen, Øster Farimagsgade 2D, DK-1353 Copenhagen K, Denmark
\end{abstract}

Submitted September 19, 2006; Accepted November 30, 2006

Monitoring Editor: C. Graham Clark

The existing data on the molecular phylogeny of filose testate amoebae from order Euglyphida has revealed contradictions between traditional morphological classification and SSU rRNA phylogeny and, moreover, the position of several important genera remained unknown. We therefore carried out a study aiming to fill several important gaps and better understand the relationships among the main euglyphid testate amoebae and the evolutionary steps that led to the present diversity at a higher level.

We obtained new SSU rRNA sequences from five genera and seven species. This new phylogeny obtained shows that (1) the clade formed by species of genera Assulina and Placocista branches unambiguously at the base of the subclade of Euglyphida comprising all members of the family Trinematidae and genus Euglypha, (2) family Trinematidae (Trachelocorythion, Trinema, and Corythion) branches as a sister group to genus Euglypha, (3) three newly sequenced Euglypha species (E. cf. ciliata, E. penardi, and $E$. compressa) form a new clade within the genus.

Since our results show that Assulina and Placocista do not belong to the Euglyphidae (unless the Trinematidae are also included in this family), we propose the creation of a new family named Assulinidae. Consequently, we give a family status to the genera Euglypha and (tentatively) Scutiglypha, which become the new family Euglyphidae.

The evolutionary pattern suggested by SSU rRNA phylogeny shows a clear tendency towards increasing morphological complexity of the shell characterised by changes in the symmetry (migration of the aperture to a ventral position and/or compression of the shell) and the appearance of specialised scales at the aperture (in families Trinematidae and Euglyphidae).

(c) 2007 Elsevier GmbH. All rights reserved.

Key words: phylogeny; testate amoebae; protist; protozoa; evolution; morphology.

Corresponding author;

fax +41216933913

e-mail edward.mitchell@epfl.ch (E.A.D. Mitchell). 


\section{Introduction}

The eukaryotic super-group Rhizaria (Adl et al. 2005 ) is a large assemblage of morphologically and ecologically dissimilar organisms, comprising both flagellate and amoeboid forms. They can be phagotrophic, secondarily phototrophic (like the Chlorarachniophyta) or parasitic (such as the Haplosporidia and the Plasmodiophorida). The rhizarian amoeboid forms are characterised by filose pseudopodia, in contrast to the lobose pseudopodia generally found in "true amoebae" belonging to the supergroup Amoebozoa. In addition, the presence of a test is a recurring feature in rhizarians, such as the Foraminifera, Gromiida and the Euglyphida.

Extant members of the Euglyphida are typical inhabitants of soil and freshwater, being most abundant in permanently wet mosses such as Sphagnum. They are chiefly bacterivorous, and seem to play an important role in the food and energy turnover of terrestrial ecosystems (Schönborn 1992). Reproduction is achieved by binary fission; there is evidence that some species at least undergo meiosis and possibly gene exchange (ludina and Sukhanova 2000; Schönborn and Peschke 1990). They are characterised by a selfsecreted siliceous test, made of scales of different size and shape, which are bound together by organic cement. The morphological classification of the species and genera is based mainly on the shape and disposition of these scales.

The order Euglyphida Copeland, 1956 is divided into four families: Paulinellidae, Cyphoderiidae, Euglyphidae and Trinematidae (Meisterfeld 2002). The first two families are characterised by a rather simple scale pattern, while the latter two often show scale dimorphism, which leads to the apparition of specialised structures on the shell, such as spines and pseudostome-surrounding "teeth". Species belonging to the family Euglyphidae secrete tests with an acrostome opening, while species from family Trinematidae are characterised by a ventrally positioned pseudostome.

Molecular phylogenetic investigation on the position of euglyphid testate amoebae date back to 1995, when Bhattacharya, Helmchen and Melkonian (Bhattacharya et al. 1995) demonstrated the position of Euglypha rotunda and Paulinella chromatophora next to the Chlorachniophyta; Cavalier-Smith (1996/1997) added to this group the sarcomonad flagellates; this assemblage of morphologically diverse organisms was later emended Cercozoa (Cavalier-Smith 1998). However, although the position of the euglyphid testate amoebae in the tree of life was clarified since then, the phylogenetic relationships within this taxon remained unresolved. Wylezich et al. (2002) first studied the relationships within this group. Their study confirmed a close relationship between all sequenced euglyphid testate amoebae, the monophyly of which is also well supported by the morphology. They also showed that the different morphospecies that could be identified within genus Euglypha using available descriptions did not correspond to monophyletic units. This confirmed the uncertain status of many forms, as pointed out previously by Coûteaux et al. (1979) on the basis of morphology. However, the position of the other genera of euglyphids, and particularly of the family Trinematidae, still remained unresolved. The low number of sequences from genera other than Euglypha led to conclusions, which were in contradiction with the morphological data, such as the grouping of the divergent Assulina and Trinema. Finally, the single sequence representing family Trinematidae (Trinema enchelys) branched inside the Euglyphidae (Wylezich et al. 2002), which did not agree with its morphological characteristics.

To shed more light on the evolution of the euglyphid testate amoebae and the phylogenetic relationships among the different taxa, we carried out a comparison of SSU rRNA-based phylogeny with the morphological classification based on light-and scanning electron microscopy. We have analysed the most common representatives of euglyphids, which are encountered in mosses and Sphagnum peat bogs (Fig. 2), and we have added these new sequences to the existing database.

\section{Results}

The obtained sequences were aligned, and a phylogenetic tree was inferred using both $M L$ and Bayesian methods; the robustness of the nodes was inferred by bootstrapping and posterior probabilities. The methods gave congruent phylogenetic trees, thus suggesting that the evolutionary relationships among investigated taxa are robust.

The two sequences from genera Paulinella and Cyphoderia branch at the base of the Euglyphida. The rest of the species appear closely related, and the addition of seven new taxa revealed the existence of three major clades; the genus Euglypha, the Trinematidae and a group formed 
by genera Placocista and Assulina (Fig. 1). The analyses presented here suggest that the order Euglyphida is monophyletic. The group formed by Placocista and Assulina appears basal to genus Euglypha and to the Trinematidae, the last two appearing as sister taxa.

The species Assulina muscorum, $A$. seminulum and the phototrophic symbiont-bearing Placocista spinosa form a clade, which obtains maximal statistical support in both Bayesian and ML analyses. The two Assulina species branch together and Placocista branches at the base. Genus Euglypha and the Trinematidae form together a clade strongly supported by Bayesian posterior probabilities, but moderately supported by ML bootstrap values. The monophyly of genus

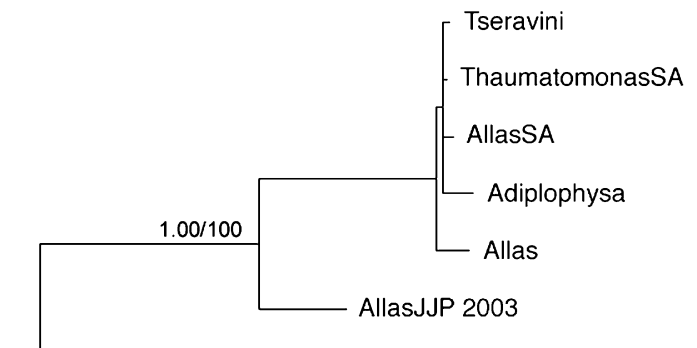

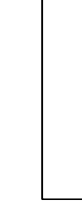
$0.87 / 76$ Cyphoderia ampulla $1.00 / 100$ $1.00 / 99$

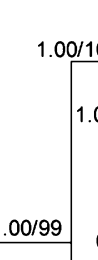

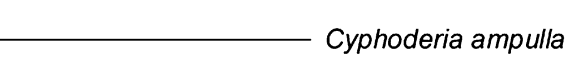

$$
\text { Placocista spinosa }
$$

- Assulina seminulum

Assulina muscorum Trachelocorythion pulchellum Trinema lineare Paulinella chromatophora

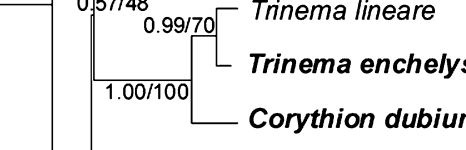
- Euglypha filifera str. Costa Rica $1.00 / 73$ $1.00 / 100$ 1.00/99 Euglypha cf. ciliata $0.89 / 501.00 / 95$ Euglypha penardi Euglypha compressa

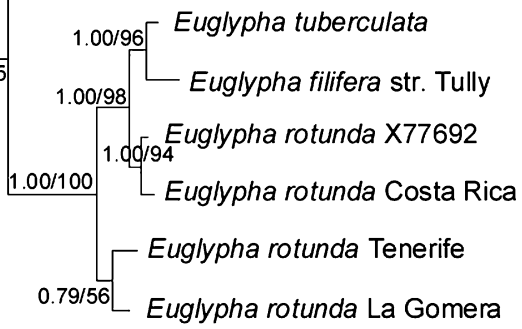
0.01 substitutions/site

- Euglypha rotunda La Gomera

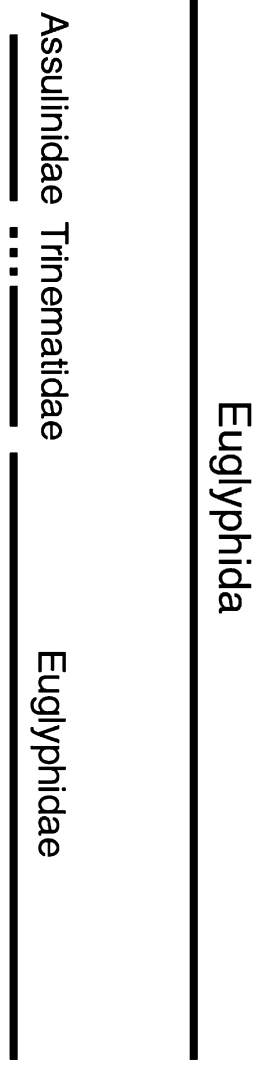

Figure 1. Maximum-likelihood tree of euglyphid testate amoebae, including all SSU rRNA gene sequences from Euglyphida present in GenBank except Tracheleuglypha dentata. The tree was rooted with six thaumatomonads. The numbers above the branches on each node indicate the posterior probabilities as calculated with Bayesian analyses and the bootstrap values obtained with ML. Bayesian values under 0.5 are omitted. 
Euglypha is well supported by both $\mathrm{ML}$ and Bayesian analyses, with the exception of the taxa E. acanthophora and E. "filifera" from Costa Rica. These two long.branch sequences are linked to genus Euglypha taxa only topologically, with very low/no support in both Bayesian and ML analyses. The large, spiny species E. compressa, E.cf. ciliata and $E$. penardi form a strongly supported clade in all analyses, E. cf. ciliata and $E$. penardi being most closely related to each other. The small, spineless species $E$. rotunda, plus $E$. tuberculata and E. filifera (Australia) also form a well-supported group. The Trinematidae Trinema lineare, $T$. enchelys and Corythion dubium form a wellsupported clade, with the two Trinema species branching together; the assignment of Trachelocorythion pulchellum to this group is much more dubious, since the statistical support of this phylogenetic position is much lower, in both Bayesian and ML methods (0.57/48).

\section{Discussion}

Our analysis clearly identified three groups of euglyphid testate amoebae. The first group comprises the genera Assulina and Placocista. All analyses show this group branching at the base of genus Euglypha/Trinematidae. This very robust clade is also supported by morphology: the strongly flattened shape of the shell characterises these two genera (Fig. 2A, B). Also, the shape of the scales is similar, strongly resembling the scales found in genus Euglypha. The scales are disposed in a regular, alternated pattern. No specialised apertural scales are found in members of this clade but some species in genus Placocista $(P$. spinosa, but also $P$. jurassica, $P$. ventricosa and $P$. lapponum, not included in this study) possess spines. Hence, we propose family status for this clade, which we name Assulinidae.

The next two clades (genus Euglypha and Trinematidae) are characterised by the presence of two or more different types of scales (Fig. 2D-H). The genus Euglypha is characterised by specialised denticulate scales surrounding the pseudostome (Fig. 2H), which are not found in any other Euglyphida (Meisterfeld 2002). While this remarkable synapomorphy supports the monophyly of the genus, the molecular phylogenetic analyses do not support the monophyly of the genus. This is likely due to the sequences of Euglypha acanthophora and "Euglypha filifera" (Costa Rica). The monophyly of the rest of the Euglypha sequences was very well supported in all ana- lyses. These sequences showed also to be divergent in the analysis of Wylezich et al. (2002), their assignation to the genus based only on SSU rDNA sequences being unclear. However, we favour the hypothesis of a monophyletic genus Euglypha, given the consistency of the morphological criteria. In this sense, and to be consistent with the new status of the Assulinidae, we propose to give the family status to this genus, which becomes then the family Euglyphidae. Until the relationships within genus Euglypha are better resolved and valuable criteria for species definition in agreement with genetic data are found, the family remains monogeneric. It is, however, highly likely that the Euglyphidae will include at least a second genus, Scutiglypha, which is characterised by the scutiform shape of the body plates (Foissner and Schiller 2001). Further morphological and molecular work is needed to clarify this.

The three newly sequenced species, Euglypha cf. ciliata, E. compressa and E. penardi (Fig. 3), form a well-supported clade. This is also consistent with their morphology and ecology: these are three large spiny species which are often found in wet forest mosses, the larger $E$. compressa being especially abundant in wet Sphagnum habitats (Booth 2001; Charman and Warner 1992; Lamentowicz and Mitchell 2005; Mitchell et al. 1999; Payne et al. 2006). Euglypha cf. ciliata and $E$. penardi, branch together. This is in agreement with their morphology: Both have an oval cross section, and their test is covered with slender spines, whereas E. compressa has a more flattened test, angular in cross section, and has spines only on the angular edge of the shell (Fig. 2). It is interesting to note the evolutionary convergence of this species with $P$. spinosa; the spines are disposed the same way, and the compressed shape of the shell is quite similar.

On morphological grounds the family Trinematidae has been considered as separate from the Euglyphidae (Meisterfeld 2002). This is justified by the ventral, often invaginated, opening of their pseudostome (Fig. 2). The shell of the studied species is built of either two types of scales (large, round and small, elliptic) in the case of Trinema, or of only one type of scale (the small and elliptic type) in the case of Corythion. These scales are disposed in an irregular pattern. In the previous work on the phylogeny of filose testate amoebae by Wylezich et al. (2002), Trinema was placed inside the rest of the Euglyphidae. In the present work, the addition of two more sequences confirms that the Trinematidae are indeed closely related to the Euglyphidae, but they now are 

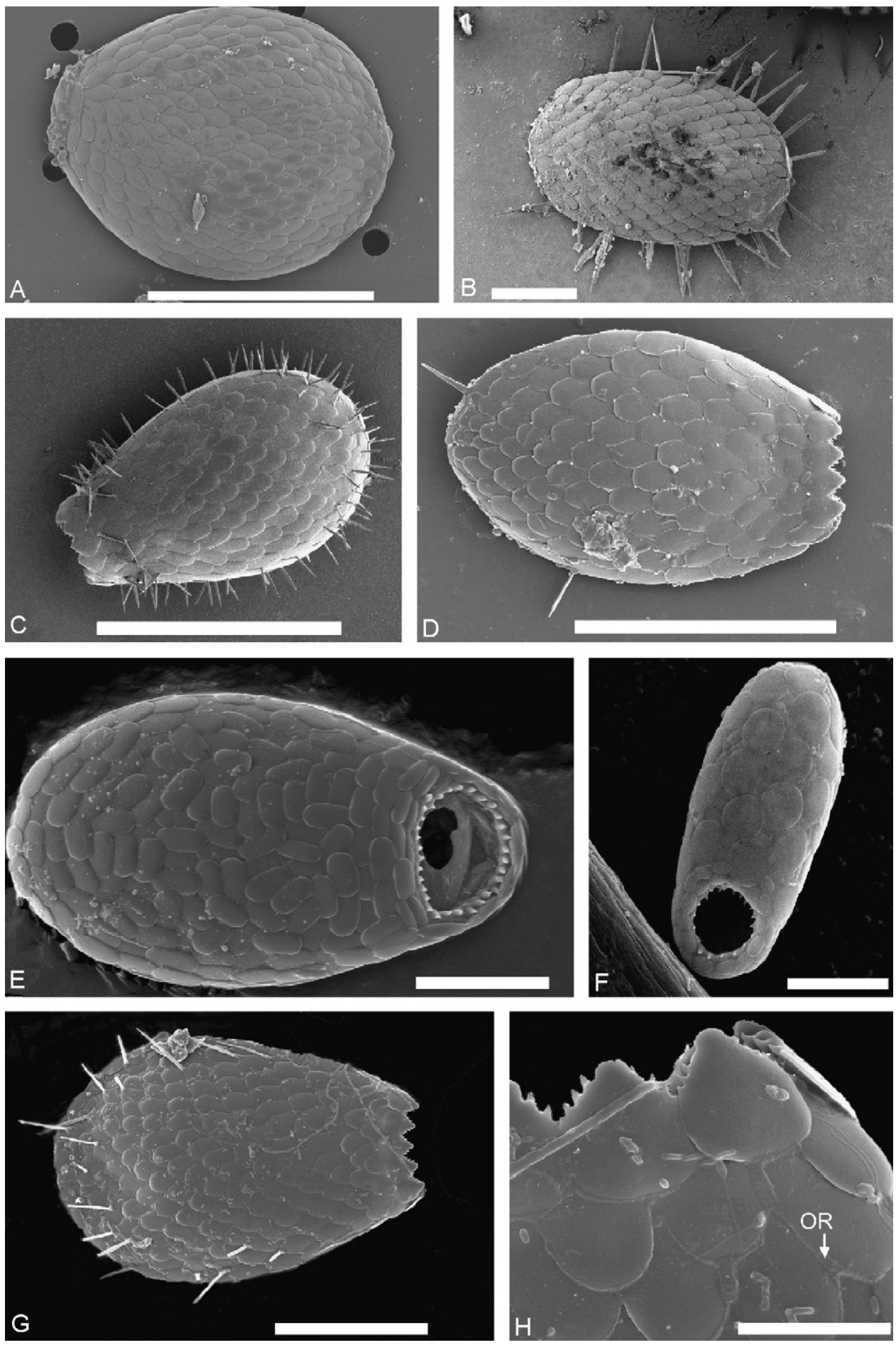

Figure 2. Scanning electron micrographs of the tests of the species studied in this manuscript. A: Assulina seminulum, B: Placocista spinosa, C: Euglypha cf. ciliata, D: Euglypha compressa, E: Corythion dubium, F: Trinema lineare, G: Euglypha penardi, H: E. penardi, detail of the pseudostome, showing the organic rin between the scales, characteristic of that species (OR). Scale bars represent $50 \mu \mathrm{m}$ in all pictures excepted pictures $\mathrm{E}, \mathrm{F}$ and $\mathrm{H}(10 \mu \mathrm{m})$. 

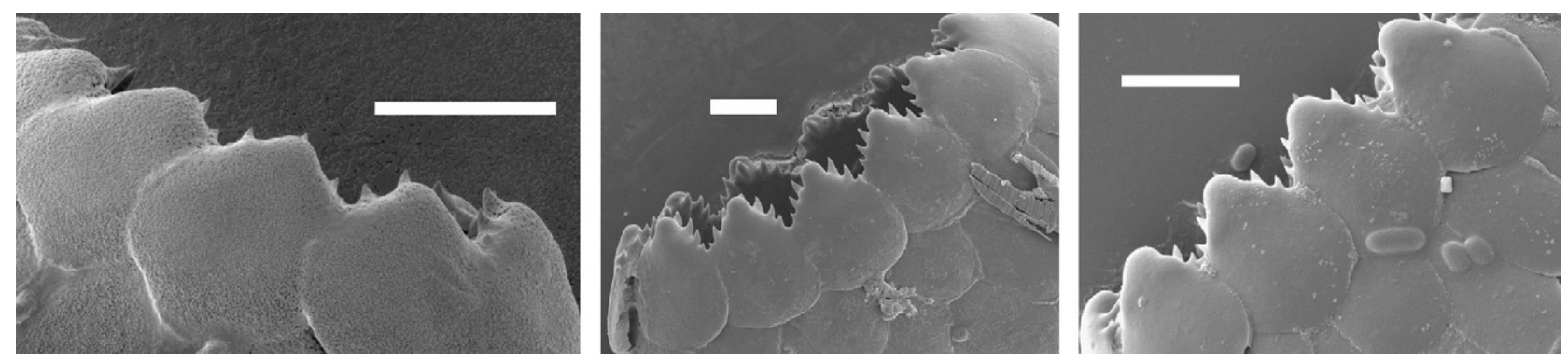

Figure 3. Scanning electron micrographs showing the denticulate plates around the pseudostome of the Euglypha species studied in this manuscript. A: Euglypha cf. ciliata, B: E. penardi, C: E. compressa. Scale bars represent $5 \mu \mathrm{m}$.

placed as a sister taxon to the family Euglyphidae. The three sequences of Trinematidae form a monophyletic, robust clade. In contrast, the affiliation of Trachelocorythion pulchellum to this group is still uncertain. From a morphological point of view, the slightly ventral position of a pseudostome surrounded by smaller scales, which may be interpreted as a transition towards the specialised "teeth" in Corythion and Trinema, could justify the assignation of this species to the family Trinematidae. However, the scales are placed in a regular alternate pattern as found in the Assulinidae and the Euglyphidae; in that sense, the morphological data place T. pulchellum as a transitional form prefiguring the family Trinematidae. In its first description, Penard (1890) included it in the genus Corythion. Later, Bonnet (1979) transferred it to a new monospecific genus, Trachelocorythion, based on the type of scales that resemble those of Euglypha spp., and the Assulina-Placocista clade, and the absence of denticulate mouth plates. Meisterfeld (2002) placed T. pulchellum in Euglyphidae (sensu lato), separately from Trinematidae. In this paper, the phylogenetic analysis joins $T$. pulchellum with the Trinematidae, although with a weak support. Hopefully, addition of new sequences will clarify its affiliation and confirm this view.

Besides the mentioned species, the fast-evolving Tracheleuglypha dentata was excluded from our analysis because it perturbed the analyses, resulting in a long branch and nodes with a low robustness. In the analyses in which $T$. dentata was included, its position was at the base of the clade formed by Trinematidae and Euglyphidae. This derived position would be in contradiction with the simple structure of its test, which only has one type of scales, a circular cross-section, and a terminal aperture. We interpret this position as a long-branch attraction artefact. Its exact position on the tree will probably be further clarified when sequences from morphologically similar species are added, as for instance Pareuglypha reticulata, which has only one type of scales and a circular cross section.

These new results based on 20 SSU rRNA gene sequences from 16 morpho-species lead us to propose an evolutionary scenario for the euglyphid testate amoebae. The ellipsoid scales disposed on a regular alternate pattern of the Assulinidae seem to be the most ancient character, the presence of polymorphic scales being a derived character. From this ancestral state appeared the specialised denticulated pseudostome plates (Euglyphidae) and the polymorphic plates of the Trinematidae. According to this interpretation, the evolution of the Euglyphida is characterised by an increasing shell complexity. The ancestral euglyphid had most likely a terminal pseudostome. In these analyses, it is clear that the ventral opening evolved from symmetric ancestors, as family Trinematidae diverged from inside the Euglyphidae. As in the case of the lobose testate amoebae Arcellinida, the ventral aperture represents an adaptation to dryer conditions which allowed the colonisation of terrestrial environments (Bonnet 1964), as these species are typically found in forest mosses and other less predictable environments (Nikolaev et al. 2005).

Based on this scenario, we can hypothesize the position of some taxa from which sequences are not available at the moment. For instance, Playfairina presents the particularities of a typical Trinematidae, while Dehvarengia and Sphenoderia share some characteristics with Trachelocorythion (one type of body scales in alternated position, smaller specialised scales around the pseudostome); sequences from these last two species could help clarify the position of T. pulchellum. The position of Pileolus is less clear, because of the 
shape of its scales is quite atypical, and its affiliation to Trinematidae remains to be demonstrated.

\section{Taxonomic summary}

\section{Eukaryota}

Rhizaria Cavalier-Smith, 2002

Cercozoa Cavalier-Smith, 1998 emend. Adl, 2005

Silicofilosea Adl, 2005

Euglyphida Copeland, 1956 emend. Cavalier-

Smith, 1997

Assulinidae fam. nov.

Definition: testate amoebae with an acrostome test that is composed of elliptic or round plates which are disposed in a regular, alternate pattern. The test is strongly compressed, and the pseudostome is surrounded by a thin organic rim. No specialised type of scales around the pseudostome.

Genera: Assulina, Placocista

Euglyphidae Wallich, 1864 emend. Lara et al., 2006

Definition: testate amoebae with an acrostome test composed of elliptic, sub-rectangular, scutiform, or almost round body plates which are disposed in a regular, alternate pattern. The pseudostome is surrounded by denticulate plates.

Genera: Euglypha, Scutiglypha?

\section{Methods}

Cell sorting and DNA extraction: For each species, between five and 20 individuals were extracted from moss samples and picked individually under the dissecting microscope using small diameter pipettes. The amoebae were washed and filtered in clean tap water. DNA was extracted using a guanidine thiocyanate protocol (Chomczynski and Sacchi 1987). The sequence of Trinema lineare was obtained from a culture (RM; the organism is available upon request). The complete list of taxa studied and sampling locations is given in Table 1.

PCR protocol and sequencing: SSU sequences were obtained in two steps, using for the first half of the SSU gene two group specific primers (euglyph1F and cercoR), and for the second half a combination of a group specific primer (euglyph 2F) and a domain specific

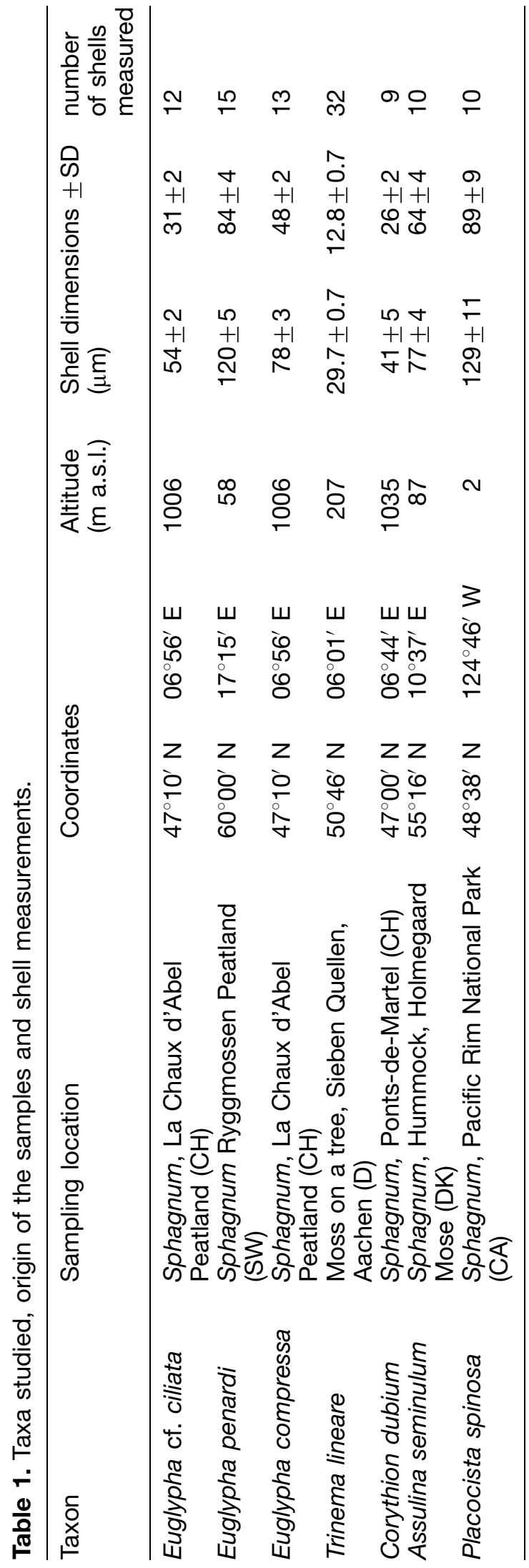


Table 2. List of the primers used in this study.

\begin{tabular}{|c|c|c|c|}
\hline Name & Sequence $5^{\prime}-3^{\prime}$ & Specificity & $\begin{array}{l}\text { Location (on } \\
\text { E. rotunda } \\
\text { X77692) }\end{array}$ \\
\hline $\begin{array}{l}\text { euglyph1F } \\
\text { euglyph2F }\end{array}$ & $\begin{array}{l}\text { ACATATGCTTGTCTCAAAGACTAAG } \\
\text { TATACCGACTMAGGATCAGTG }\end{array}$ & $\begin{array}{l}\text { Euglyphidae+Trinematidae } \\
\text { Euglyphidae+Trinematidae, } \\
\text { except Tracheleuglypha dentata }\end{array}$ & $\begin{array}{r}23 \\
1045\end{array}$ \\
\hline $\begin{array}{l}\text { cercoR } \\
\text { Euk3b' }\end{array}$ & $\begin{array}{l}\text { GGTCGAGGTCTCGTTCGTTAACGG } \\
\text { ATCCTTCYGCAGGTTCAC }\end{array}$ & $\begin{array}{l}\text { Most cercozoa } \\
\text { Most eukaryotes }\end{array}$ & $\begin{array}{l}1331 \\
1793\end{array}$ \\
\hline
\end{tabular}

eukaryotic primer (Euk3b'). The sequences of these primers as well as their specificity are given in Table 2. The reason for this indirect protocol is that it is virtually impossible to remove eukaryotic contaminants (mainly fungi) by washing the cells, owing to undigested preys, epibionts and also the presence of symbionts in Placocista spinosa. Both first and second parts of the SSU gene were amplified using the following PCR protocol: a first denaturation at $95^{\circ} \mathrm{C}(5 \mathrm{~min})$, followed by 35 cycles of $94^{\circ} \mathrm{C}$ for $45 \mathrm{~s}, 58^{\circ} \mathrm{C}$ for $60 \mathrm{~s}$ and $72^{\circ} \mathrm{C}$ for $90 \mathrm{~s}$; final extension at $72^{\circ} \mathrm{C}$ for $10 \mathrm{~min}$. The PCR products where purified with the NucleoFast $\mathbb{R} 96$ PCR Clean Up kit from Macherey-Nagel (Düren, Germany) and sequenced at MWG Biotech (Martinsried, Germany) and Fraunhofer IME (Aachen, Germany). The sequencing primers were the same as the ones used for PCR.

Phylogenetic analysis: The SSU rRNA gene sequences obtained in this study were aligned manually using the BioEdit software (Hall 1999). Other sequences belonging to the Silicofilosea were introduced into the analysis; the Thaumatomonadida being used as outgroups in the phylogenetic analyses. This order is considered as the sister-group of the Euglyphida (Adl et al. 2005). The highly divergent sequence Tracheleuglypha dentata was not taken into account in the analysis because the branch it formed with rest of the Euglyphida was significantly longer than the other branches and perturbed the analyses; the topology of the tree was identical, but nodes were less supported; $T$. dentata appeared at the base of the group formed by Trinematidae and Euglypha (data not shown). A total of 1613 positions were kept for phylogenetic analyses. The alignment is available from the authors upon request. A maximum likelihood tree was built using the program PAUP* 4.0 b10 (Swofford 1998). The best likelihood model was inferred using the software Modeltest v3.06 (Posada and Crandall 1998). The model chosen was the $\mathrm{TIM}+\mathrm{G}+\mathrm{I}$. A total of 1000 bootstrap replicates were run under this model.
In addition, a Bayesian analysis was achieved using the software MBayes v. 3.1.2 (Huelsenbeck and Ronquist 2001). Four simultaneous chains were run for 1,000,000 generations, and 10,000 trees were sampled, 50 of which were discarded as the burn-in. The model chosen here was the GTR model of substitution, with five rate categories (Lanave et al. 1984; Rodriguez et al. 1990), the number of invariable sites being estimated, and a gamma-shaped distribution of variable sites. Posterior probabilities at all nodes were estimated from the 9950 remaining trees. The tree obtained with maximum likelihood and the one obtained with Bayesian analysis had the same topology (see Fig. 1)

SEM microscopy observations: Tests were fixed in $6 \%$ glutaraldehyde before dehydration. The tests were then rinsed with demineralised water, $70 \%$ ethanol and finally with $95 \%$ ethanol. Tests were then kept 1 week in a desiccator. The samples were coated with gold in a Bal-Tec SCD005 sputter, and also in a Bio Rad Polaron division SEM Coating system A5400. Samples were observed alternatively in a PHILIPS ESEM $\mathrm{XL} 40$ microscope at a tension of $10 \mathrm{kV}$ and in a XL30 FEG at a voltage of $5 \mathrm{kV}$.

\section{Acknowledgements}

This work was funded by Swiss NSF project no. 205321-109709/1, and EU project RECIPE project (reconciling commercial exploitation of peat with biodiversity in peatland ecosystems). RECIPE was partly supported by the European Commission, Directorate I, under the programme "Energy, Environment and Sustainable Development" (no. EVK2-2002-00269) and partly, for the Swiss partners, by the OFES (Swiss federal office for education and science), Switzerland. We thank Marcel Hollenstein (University of British Columbia, Vancouver) for the moss samples from Pacific Rim National Park, Claus Baggesen and Helle 
Wilken-Jensen for the help at the lab and especially at the SEM, for the pictures of Assulina seminulum. Our gratitude for help at the SEM goes also to Michèle Vlimant and Peter Allan Diehl at the laboratory of animal physiology (Université de Neuchâtel) and also to Fabienne Bobard and Marco Cantoni at the CIME (EPFL). Thanks also $t$ Trine Koch (University of Copenhagen) for providing the sequence of the reverse primer cerco $R$. We are indebted to two anonymous reviewers and Michael Melkonian for constructive criticism on the manuscript.

\section{References}

Adl SM, Simpson AGB, Farmer MA, Andersen RA et al. (27 authors) (2005) The new higher level classification of eukaryotes with emphasis on the taxonomy of protists. J Eukaryot Microbiol 52: 399-451

Bhattacharya D, Helmchen T, Melkonian M (1995) Molecular evolutionary analyses of nuclear-encoded small subunit ribosomal RNA identify an independent rhizopod lineage containing the Euglyphina and the Chlorarachniophyta. J Eukaryot Microbiol 42: 65-69

Bonnet L (1964) Le peuplement thécamoebiens des sols. Rev Ecol Biol Sol 1: 123-408

Bonnet L (1979) Nouveaux thécamoebiens du sol. X Bull Soc Hist Nat Toulouse 115: 106-118

Booth RK (2001) Ecology of testate amoebae (Protozoa) in two Lake Superior coastal wetlands: Implications for paleoecology and environmental monitoring. Wetlands 21: $564-576$

Cavalier-Smith T (1996/1997) Amoeboflagellates and mitochondrial cristae in eukaryotic evolution; megasystematics of the new protozoan subkingdoms Eozoa and Neozoa. Arch Protistenkd 147: 237-258

Cavalier-Smith T (1998) A revised six-kingdom system of life. Biol Rev Camb Philos Soc 73: 203-266

Charman DJ, Warner BG (1992) Relationship between testate amoebae (Protozoa, Rhizopoda) and microenvironmental parameters on a forested peatland in Northeastern Ontario. Can J Zool 70: 2474-2482

Chomczynski P, Sacchi N (1987) Single-step method of RNA isolation by acid guanidinium thiocyanate-phenol-chloroform extraction. Anal Biochem 162: 156-159

Coûteaux MM, Munsch A, Ponge JF (1979) Le genre Euglypha: essai de taxinomie numérique (in French). Protistologica 15: 565-579

Foissner W, Schiller W (2001) Stable for 15 million years: scanning electron microscope investigation of Miocene euglyphid thecamoebians from Germany, with description of the new genus Scutiglypha. Europ J Protistol 37: 167-180
Hall TA (1999) BioEdit: a user-friendly biological sequence alignment editor and analysis program for Windows 95/98/NT. Nucleic Acids Symp Ser 41: 95-98

Huelsenbeck JP, Ronquist F (2001) MrBayes: Bayesian inference of phylogenetic trees. Bioinformatics 17: $754-755$

ludina TA, Sukhanova KM (2000) Cell biology and life cycle of the testate amoeba Corythion delamarei. Tsitologiia 42: $613-623$

Lamentowicz M, Mitchell EAD (2005) The ecology of testate amoebae (Protists) in Sphagnum in north-west Poland in relation to peatland ecology. Microb Ecol 50: 48-63

Lanave C, Preparata G, Saccone C, Serio G (1984) A new method for calculating evolutionary substitution rates. $\mathrm{J}$ Mol Evol 20: 86-93

Meisterfeld R (2002). Testate Amoebae with Filopodia. In Lee JJ, Leedale GF, Bradbury P (eds), The Illustrated Guide to the Protozoa. 2nd Ed, vol. 2, Society of Protozoologists, Lawrence, Kansas, USA, pp 1055-1084

Mitchell EAD, Buttler AJ, Warner BG, Gobat JM (1999) Ecology of testate amoebae (Protozoa: Rhizopoda) in Sphagnum peatlands in the Jura mountains, Switzerland and France. Ecoscience 6: 565-576

Nikolaev SI, Mitchell EAD, Petrova NB, Berney C, Fahrni J, Pawlowski J (2005) The testate lobose amoebae (Order Arcellinida, Kent, 1880) finally find their home within Amoebozoa. Protist 156: 191-202

Payne R, Kishaba K, Blackford J, Mitchell EAD (2006) The ecology of testate amoebae (Protists) in South-Central Alaska peatlands: building transfer function models for paleoenvironmental studies. Holocene 16: 403-414

Penard E (1890) Etudes sur les rhizopodes d'eau douce. Mem Soc Phys Hist Genève 31: 1-230

Posada D, Crandall KA (1998) MODELTEST: testing the model of DNA substitution. Bioinformatics 14: 816-817

Rodriguez F, Oliver J, Marin A, Medina JR (1990) The general stochastic model of nucleotide substitution. J Theor Biol 142: $485-501$

Schönborn W (1992) Comparative studies on the production biology of protozoan communities in freshwater and soil ecosystems. Arch Protistenkd 141: 187-214

Schönborn W, Peschke T (1990) Evolutionary studies on the Assulina-Valkanovia complex (Rhizopodia, Testatceafilosia) in Sphagnum and in Soil. Biol Fert Soils 9: 95-100

Swofford DL (1998) PAUP*: Phylogenetic Analyses Using Parsimony ("and other Methods). Sinauer Associates, Sunderland, MA

Wylezich C, Meisterfeld R, Meisterfeld S, Schlegel M (2002) Phylogenetic analyses of small subunit ribosomal RNA coding regions reveal a monophyletic lineage of euglyphid testate amoebae (Order Euglyphida). J Eukaryot Microbiol 49: $108-118$ 